\begin{tabular}{|l|l|l|}
\hline Received : Agustus 2017 & Accepted : September 2017 & Published : Oktober 2017 \\
\hline
\end{tabular}

\title{
Rancang Bangun Sistem Smart Library pada Perpustakaan SMK Airlangga Balikpapan
}

\author{
Richki Hardi \\ Program Studi Teknik Informatika \\ STMIK Balikpapan, Kalimantan Timur, Indonesia \\ richki@stmikbpn.ac.id
}

\begin{abstract}
The design of the Smart Library system is designed and developed to help improve reading interest among teenagers, as long as the interest of reading, especially on Indonesian teenagers is still classified into less categories while reading facilities or libraries and the availability of books read is very much. Smart library system is also presented to help the management of modern library with various facilities to provide convenience, speed and accuracy of library management process based on information technology, which has the main entities, namely collection management, member management, collection circulation management, collection tracking, attendance and reporting so as to facilitate the process of borrowing and borrowing books, collections and more. Smart libraries can be operated on both computer and mobile devices as they can be accessed globally or online.
\end{abstract}

Keywords : books, mobile library, smart library, online library.

\begin{abstract}
Abstrak
Rancang Bangun sistem Smart Library didesain dan dikembangkan untuk membantu meningkatkan daya minat baca bagi kalangan remaja, karena selama ini minat baca khususnya pada remaja Indonesia masih tergolong dalam kategori kurang sementara fasilitas baca atau perpustakaan dan ketersediaan buku baca sudah sangat banyak. Sistem smart library juga dihadirkan untuk membantu manajemen perpustakaan modern dengan berbagai fasilitas untuk memberikan kemudahan, kecepatan dan keakuratan proses pengelolaan perpustakaan berbasis teknologi informasi, yang mempunyai entitas pokok, yaitu pengelolaan koleksi, pengelolaan anggota, pengelolaan sirkulasi koleksi, penelusuran koleksi, absensi anggota serta pelaporannya sehingga memudahkan dalam proses manajemen pinjam meminjam buku, koleksi dan lainnya. Smart library dapat dioperasikan pada perangkat computer maupun mobile karena dapat diakses secara global atau online.
\end{abstract}

Kata kunci : buku, mobile library, smart library, perpustakaan online

\section{Pendahuluan}

\subsection{Latar Belakang}

Salah satu ciri organisasi modern adalah kemampuan beradaptasi terhadap perubahan yang terjadi pada lingkungan sekitarnya. Organisasi atau dalam hal ini adalah institusi tidak hanya sekedar dituntut melakukan perubahan akan tetapi lebih bagaimana menyikapi dan beradaptasi dengan perubahan itu sendiri. Teori "survival of the fittest" Charles Darwin (1809-1882) menyatakan "bukan yang terkuat yang mampu bertahan, melainkan yang paling adaptif dalam merespons perubahan" [1]. Artinya, bukan seberapa besar dan kuat suatu organisasi yang akan menjamin kesuksesan dalam memenangkan perubahan, akan tetapi organisasi yang mampu menyikapi dengan cepat dan tepat perubahan yang terjadi. Sejenak mereview bagaimana 'kejatuhan' raksasa bisnis seperti Blackberry, Kodak, Nokia, dan Yahoo karena terlambat 
beradaptasi dengan perubahan yang terjadi, dan merasa bahwa teknologi mereka masih yang terbaik dan mampu bertahan, nyatanya tergerus dengan kedatangan Google, Android, dan Samsung yang menghadirkan teknologi lebih baru dan adaptif.

Dalam arti tradisional, perpustakaan adalah sebuah koleksi buku dan majalah. Walaupun dapat diartikan sebagai koleksi pribadi perseorangan, namun perpustakaan lebih umum dikenal sebagai sebuah koleksi besar yang dibiayai dan dioperasikan oleh sebuah kota atau institusi, dan dimanfaatkan oleh masyarakat yang rata-rata tidak mampu membeli sekian banyak buku atas biaya sendiri [2].

Perkembangan teknologi dan pengetahuan yang sedemikian pesat memunculkan apa yang dinamakan dengan era digital, yang juga ditandai dengan lahirnya generasi digital. Hal ini menuntut adanya perubahan yang adaptif bagi setiap organisasi atau institusi termasuk perpustakaan dalam memberikan layanan kepada generasi 'baru' ini. Apabila dalam beberapa puluh tahun lalu fokus perubahan di perpustakaan pada keberadaan generasi tradisional, maka pada beberapa tahun ini terutama di sekolah sudah harus bergeser pada generasi digital. Hal ini dikarenakan dominasi jumlah generasi digital yang semakin tinggi dalam lingkungan sekolah.

Perpustakaan SMK Airlangga Balikpapan merupakan perpustakaan dengan koleksi buku baca yang cukup banyak, begitu pula dengan majalah, CD, buku ajar atau buku referensi, serta jurnal. Sebagai lembaga pendidikan memiliki komitmen penuh dalam mengembangkan ilmu pengetahuan. Koleksikoleksi yang dimiliki perpustakaan SMK Airlangga Balikpapan secara umum digolongkan menjadi dua, yaitu yang digunakan untuk mendukung pelajaran seharihari berupa buku bacaan untuk siswa dan buku-buku referensi atau acuan siswa baik berbahasa Indonesia maupun bahasa asing yang digunakan dengan tujuan pengembangan ilmu dan teknologi.

Perpustakaan merupakan salah satu sarana penunjang yang membantu dalam penyediaan sumber informasi dalam proses pendidikan, karena perpustakaan memberikan fasilitas peminjaman buku tanpa dibebani biaya apapun. Untuk memperlancar proses layanan pencarian dan peminjaman oleh peminjam terhadap perpustakaan dibutuhkan sebuah sistem yang memudahkan para anggota perpustakaan dalam mengakses layanan perpustakaan khususnya proses peminjaman buku. Aplikasi ini nantinya juga menyediakan fasilitas yang membantu dalam pencarian buku yang dilakukan oleh anggota perpustakaan, sistem juga akan memberitahukan apakah buku yang akan dipinjam tersedia atau tidak serta statusnya sedang dipinjam atau tidak. Sistem juga memberi kemudahan dalam pencarian buku, buku bisa dicari dengan opsi berdasarkan judul, pengarang, jenis ataupun penerbit.

\subsection{Smart Library}

Definisi smart library sebagai berikut: "Smart Library is the concept and practice of the modern library sustainable development, based on digital, networked and intelligent information technology, with interconnection, high efficiency and convenience as the main features, and green development and digital for the general public as the essential pursuit [3]".

Selain itu "smart libraries" dapat terkait dengan bagaimana perpustakaan menggunakan "smart technology", mendukung "smart initiatives", mendukung "smart communities" dan mendukung "smart ways of working [4].

"smart libraries" sebagai perpustakaan yang "flexible, adaptive, extendible, acknowledging and human" dimana memberikan layanan yang interactive, innovative, informative, actual, changing dan international [5]. 
Ketiga definisi di atas memperlihatkan bahwa smart libraries didefinisikan sebagai sebuah perpustakaan yang mampu memberikan "layanan pintar" atau "smart services" berbasis pada smart technology dan perubahan kebutuhan dari para pemustakanya terutama dari generasi digital.

\subsection{Konsep Smart Library}

Konsep smart library sebetulnya sangat berdekatan dan ada keterkaitan dengan digital library, walaupun kedua memiliki karakteristik masing-masing. Keduanya sama-sama berbasis pada digitization dan networking, akan tetapi dalam smart library sudah dikombinasikan dengan intelligence technology, keberagaman budaya, dan interaksi social Smart library bukan sekedar perluasan perpustakaan secara fisik akan tetapi lebih dari itu dimana fokus pada layanan prima perpustakaan dan manajemen berkualitas tinggi dengan dukungan Teknologi Informasi. Hal ini direpresentasikan dengan interkoneksi, efisiensi yang tinggi dan kenyamanan [3]. Pada beberapa sumber disebutkan bahwa Smart Library juga digambarkan sebagai sebuah "Intelligence Library" yang erat kaitannya dengan penerapan konsep Library.

Karakteristik dan ciri-ciri sebuah Smart Library setidaknya mencakup 5 (lima) hal SMART berikut ini:

\section{Smart Technology}

Smart Library harus mampu menghadirkan teknologi pintar di perpustakaan. Teknologi pintar disini dalam konteks perangkat keras maupun perangkat lunak serta perangkat pendukung yang lain. Perangkat keras misalnya adalah pemanfaatan perangkat wireless, RFID dan mobile devices dalam pelayanan di perpustakaan. Selain itu pemanfaatan teknologi multimedia berbasis smart misal pemanfaatan Smart TV sebagai media akses interaktif dan dinamis bagi para pemustaka. Pemanfaatan teknologi e-money dan cashless payment juga menjadi satu bentuk dari pemanfaatan teknologi pintar di perpustakaan. Pada sisi aplikasi, aplikasi berbasis mobile masih menjadi satu ciri yang paling utama, namun aplikasi yang saling terkoneksi, terintegrasi dan berbasis jaringan global menjadi sisi penting lainnya.

Pemanfaatan teknologi berbasis Augmented Reality, GPS Locations, Games, dan artificial intelligence merupakan hal lain yang juga penting untuk dipertimbangkan dalam pengembangan Smart Library.

\section{Smart Environment}

Hal penting lain dalam smart library adalah pembentukan lingkungan pintar di perpustakaan. Pembentukan lingkungan pintar harus dimulai dengan pola dan strategi pengelolaan perpustakaan yang fleksibel, adaptif, mudah untuk dikembangkan, dan mengikuti pola perilaku pemustaka atau generasi digital natives. Lingkungan pintar inilah yang akan membentuk satu komunitas pintar di perpustakaan. Pengembangan lingkungan pintar harus dapat dilakukan melalui desain interior perpustakaan, desain sistem, desain prosedur atau proses bisnis, infrastruktur hingga kepada desain gedung perpustakaan. Perencanaan terhadap keempat hal tersebut sangat penting untuk menciptakan satu lingkungan yang dapat mendukung bagi terciptanya sebuah komunitas dan layanan pintar.

\section{Smart Services}

Fokus layanan pada smart library adalah bagaimana menghadirkan kemudahan akses pemustaka kepada layanan dan juga sumber daya informasi yang dimiliki oleh perpustakaan. Sebagai contoh adalah pemanfaatan alert system yang memungkinkan pemustaka mendapatkan berbagai notifikasi peminjaman koleksi, denda, layanan terbaru, pemesanan buku dan informasi layanan pribadi lainnya dengan memanfaatkan baik email, sms, mobile apps account, maupun 
social media. Hal ini juga dapat dilihat dengan kemudahan pemustaka menjangkau komunikasi dengan pustakawan atau pengelola perpustakaan terkait layanan perpustakaan.

Pelayanan berbasis sumber daya digital dan jejaring global juga menjadi faktor penting dalam smart library. Pemanfaatan single account untuk dapat mengakses berbagai sumber daya digital kapanpun dan dimanapun (layanan anytime anywhere) yang dimiliki oleh perpustakaan harus menjadi bagian yang tidak terpisahkan dalam layanan pintar perpustakaan. Namun, implementasi smart services harus didukung dengan adanya smart technology, smart environment, smart communities dan juga smart librarians.

\section{Smart Communities/Users}

Keberadaan generasi digital merupakan komponen penting dalam smart library. Smart Library akan menciptakan satu komunitas pintar (smart users) yang secara cepat akanmenyesuaikan dengan perubahan orientasi cara perpustakaan dalam melayani mereka. Smart Communities/Users adalah mereka yang secara aktif siap menggunakan dan memanfaatkan smart technology, smart services dan menyesuaikan dengan smart environment yang ada di perpustakaan. Generasi digital natives merupakan generasi yang sangat siap sebagai smart communities. Kebiasaan mereka memanfaatkan smart devices, intensitas interaksi sosial, berjejaring, dan perilaku yang tidak dapat lepas dari teknologi menjadi kekuatan dari smart communities.

\section{Smart Librarians/Staff}

Komponen lain selain keberadaan smart communities adalah kesiapan pustakawan atau staf perpustakaan dalam smart library. Selain pemustaka yang harus mempunyai kemampuan dan keterampilan memanfaatkan berbagai smart technology [6], pustakawan juga harus dapat menjadi pustakawan pintar. Yakni pustakawan yang mempunyai keahlian dalam pemanfataan berbagai perangkat pintar, paham kebutuhan pemustaka dari generasi digital, paham pola perilaku pemustaka, dan harus menyediakan waktu lebih untuk selalu siap memberikan layanan kepada pemustaka dan juga meningkatkan pengetahuannya. Selain memberikan pelayanan, maka pustakawan pintar harus mampu memposisikan dirinya sebagai pembimbing, konsultan, bahkan pendamping pemustaka dalam melakukan eksplorasi terhadap pengetahuan dan informasi yang dibutuhkan, [3] menyatakan bahwa pengembangan smart library tidak mungkin dilakukan tanpa personal yang mempunyai kualitas tinggi (high-qualified personal). Dimana menurut keduanya pustakawan harus meningkatkan kemampuannya secara terus menerus bagaimana menggunakan teknologi baru, layanan berbasis-web (online), melakukan inisiasi dan menjaga hubungan antara perpustakaan dengan organisasi lain untuk keperluan resource sharing. Kelima karakteristik di atas tentu dapat dikembangkan sesuai dengan kebutuhan dan situasi masingmasing perpustakaan. Namun setidaknya dengan berpedoman pada kelima karakteristik di atas maka kita dapat mulai melakukan inisiasi pengembangan sebuah smart library.

Implementasi smart library sendiri sebetulnya bisa dilakukan dari hal yang sederhana. Sebagai contoh adalah di perpustakaan University of Oulu, Finlandia pada tahun 2003 yang memanfaatkan aplikasi mobile untuk memberikan kemudahan bagi pengguna menemukan buku dan koleksi lainnya di perpustakaan berbasis petunjuk peta [7]. Implementasi lain di Siberian Federal University, smart library dikembangkan dengan memanfaatkan teknologi informasi modern [8], sebagai contoh adalah kemungkinan mempelajari kebutuhan informasi pengguna melalui instrumen teknologi informasi. Jadi setiap pengguna mempunyai rekaman data belajar yang tersimpan dalam 'learning support system". 
Data inilah yang digunakan untuk menganalisis kebutuhan informasi pengguna hingga ke subyek- subyek tertentu [5]. Selain itu di Siberian Federal University terdapat interactive service melalui personal account untuk sivitas akademika yang memungkinkan mereka mengontrol aktivitas mereka dan mendapatkan berbagai informasi secara online. Dan yang paling penting bahwa layanan itu memungkinkan hubungan yang lebih baik antara perpustakaan dan pemustakanya [9].

\section{Metoda Penelitian}

\subsection{Metode \\ Sistem}

Dalam pengembangan sistem ini digunakan metode pengembangan Waterfall. Metode Waterfall merupakan metode pengembangan perangkat lunak yang secara umum dilakukan oleh para peneliti sistem, dengan melalui beberapa tahapan penelitian yaitu Analisis, Design, Coding, Testing, dan Maintenance [10]. Metode pengembangan sistem model Waterfall sebagai berikut.

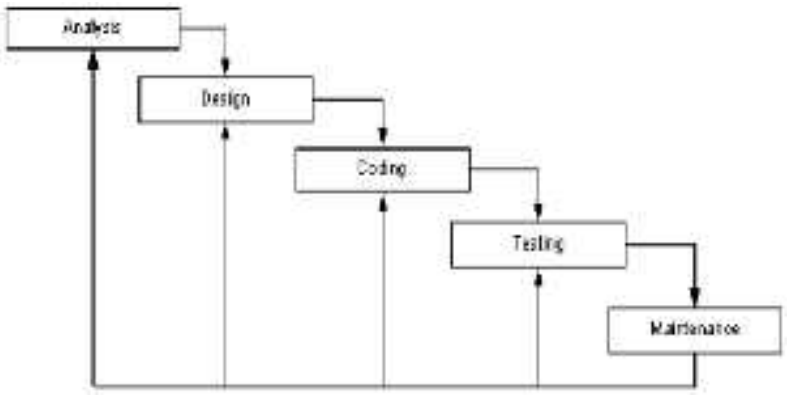

Gambar 1. Pengembangan waterfall

Analisa metode yang digunakan dalam penelitian ini adalah sebagai berikut:

Desain Sistem

Desain sistem dalam pengembangan perangkat lunak yang digunakan dalam penelitian ini, antara lain [11]:

a. Defining System

Mendefinisikan persyaratan sistem yang menentukan spesifikasi dari aplikasi mobile desain sistem perpustakaan.
Persyaratan sistem termasuk data anggota perpustakaan, data di perpustakaan, perpustakaan kategori pengumpulan data dan aliran sistem informasi perpustakaan yang ada.

b. Sistem dan Software Design

Setelah spesifikasi sistem diperoleh, maka langkah selanjutnya merancang sebuah aplikasi yang akan dikembangkan. Proses perancangan meliputi merancang menu, interface dan database.

\section{c. Use Case Diagram}

Dari panduan sistem yang ada, maka dapat digambarkan diagram use case berikut.

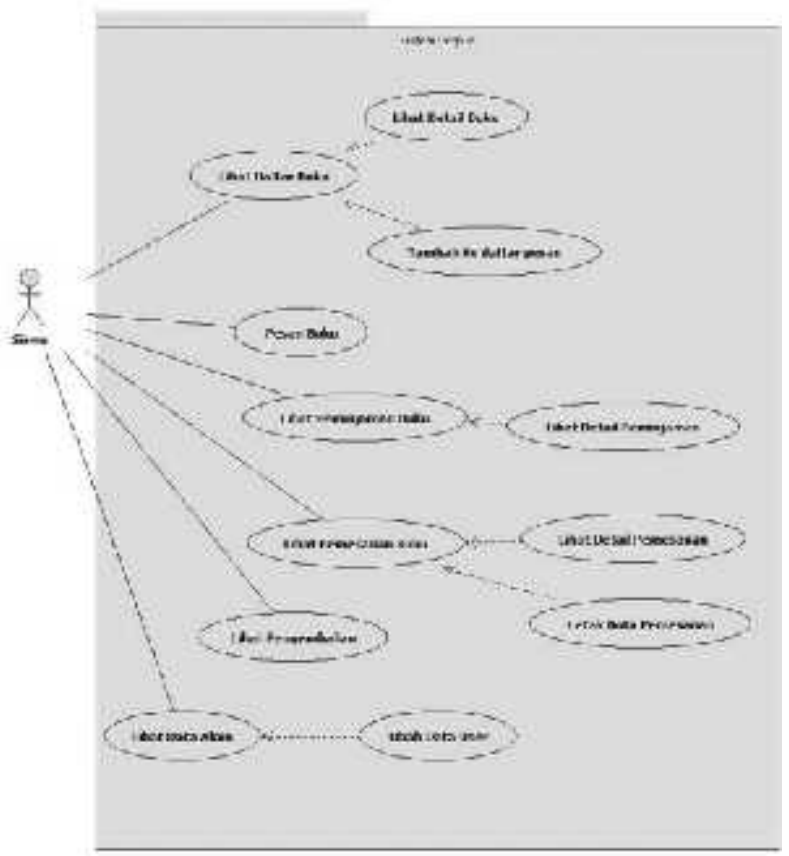

Gambar 2. Usecase diagram admin

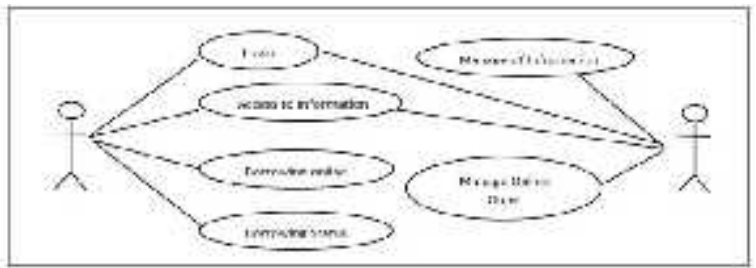

Gambar 3. Usecase diagram 


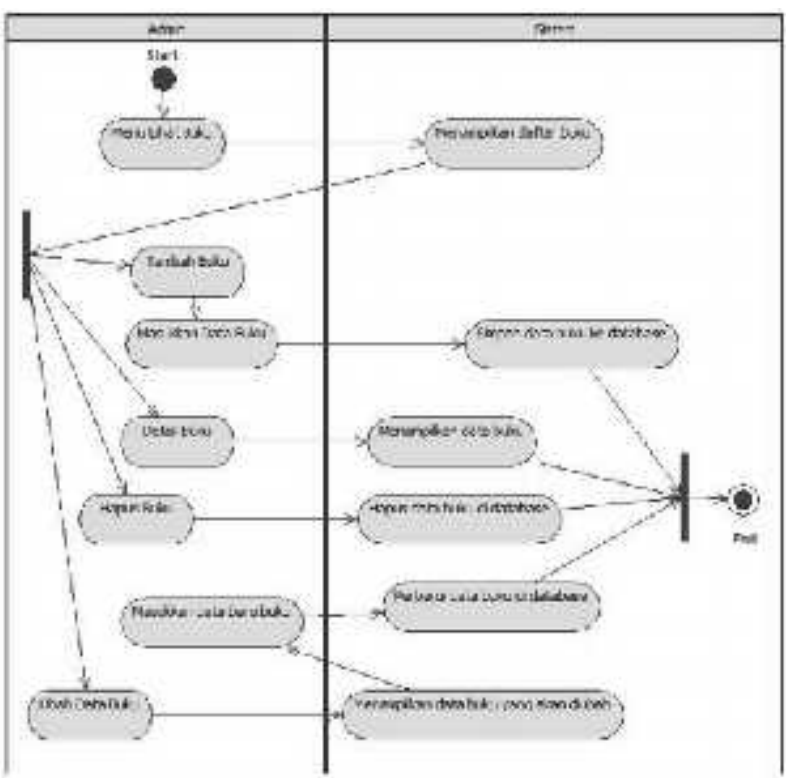

Gambar 4. Activity diagram menu buku

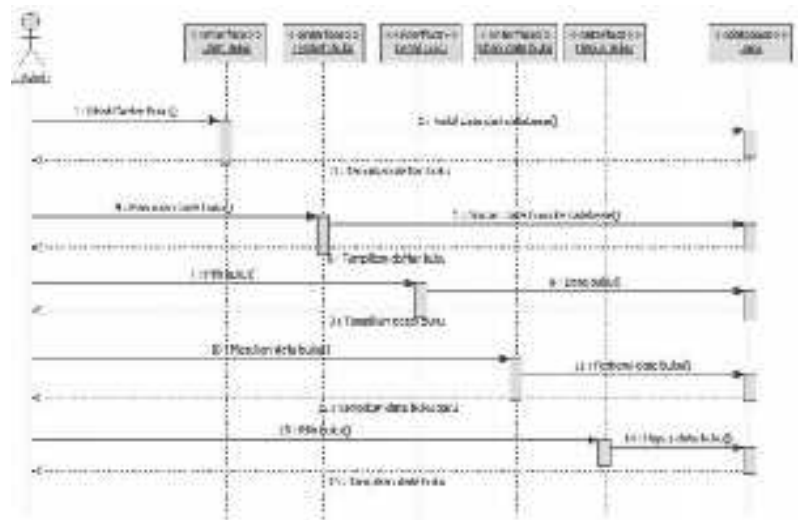

Gambar 5. Squence diagram menu buku

\section{Hasil Penelitian}

\subsection{Perancangan Sistem}

Rancangan aplikasi pada sistem ini dibangun menggunakan pemrograman Php, yang dapat diakses pada perangkat teknologi maupun mobile dengan media penyimpanan menggunakan MySQL sebagai basisdata. Berikut alur sistem dan rancangan basisdata.

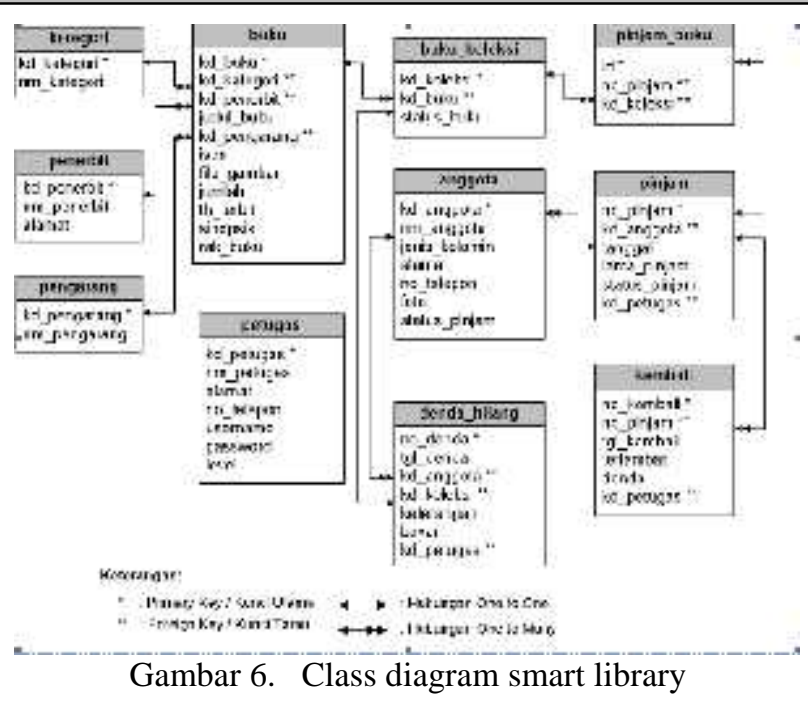

Dari hasil perangcangan tersebut maka dapat diterapkan sistem aplikasi untuk dapat diimplementasikan.

\subsection{Implementasi Sistem}

Pada tahap akhir ini, telah dibangun sebuah aplikasi dari hasil perancangan diatas. Berikut beberapa tampilan hasilnya.

Tampilan login, pada tampilan ini user akan diberikan security berupa username, password dan level agar dapat masuk dan mengakses layanan yang telah disediakan.

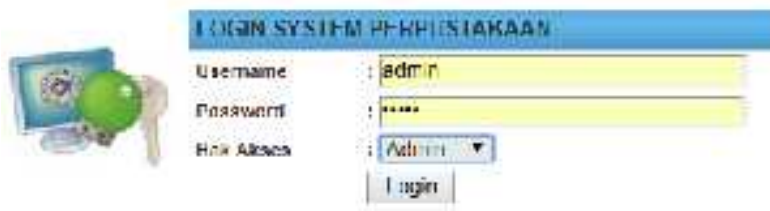

Gambar 7. Menu tampilan login

Tampilan menu data petugas, tambah data, view, edit dan delete data petugas

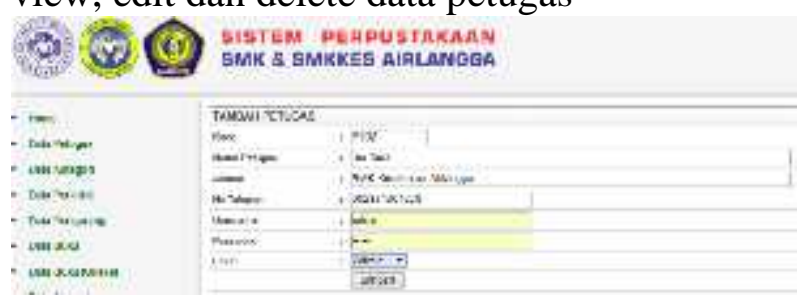

Gambar 8. Menu tampilan petugas 
Tampilan menu transaksi pinjam, pada menu ini sistem dapat membaca barcode yang tertera pada kartu pustaka dan buku pustaka.

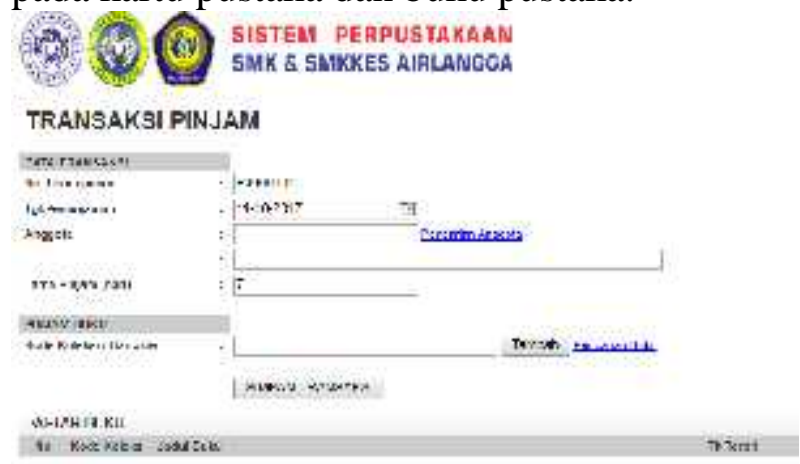

Gambar 9. Menu tampilan transaksi pinjam

Menu tampilan transaksi kembali, pada menu ini juga difasilitasi barcode pada data anggota dan memanggil data buku yang akan dikembalikan.

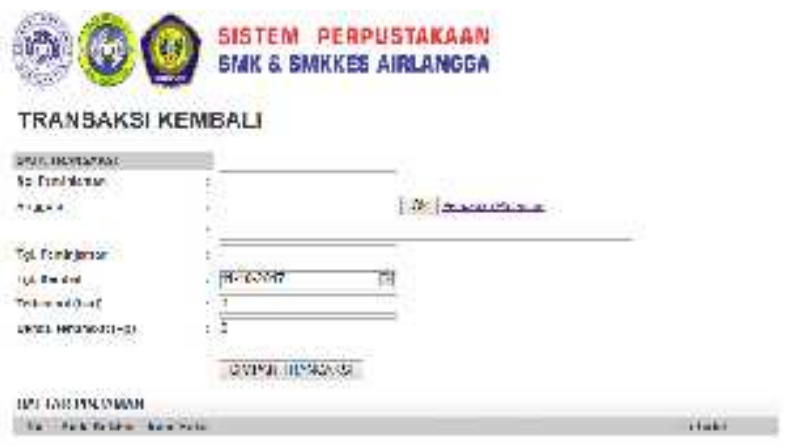

Gambar 10. Menu tampilan transaksi kembali

Dari hasil implementasi, maka dapat dilihat dan dinalisa bahwa tampilan dan penggunaan smart library pada sekolah SMK Airlangga jauh lebih efektif dan efisien.

\section{Kesimpulan}

Dari hasil implementasi, maka dapat disimpulkan bahwa aplikasi smart library yang telah dibangun pada SMK Airlangga berjalan dengan baik dan efektif. Siswa maupun guru juga dapat menerapkan proses pinjam meminjam secara sistematis dan petugas perpustakaan dapat dangan mudah mengoperasikan sistem otomatisasi smart library. Dari hal itu juga dapat dilihat bahwa grafik pengunjung perpustakaan pada SMK Airlangga juga meningkat dari sebelumnya.

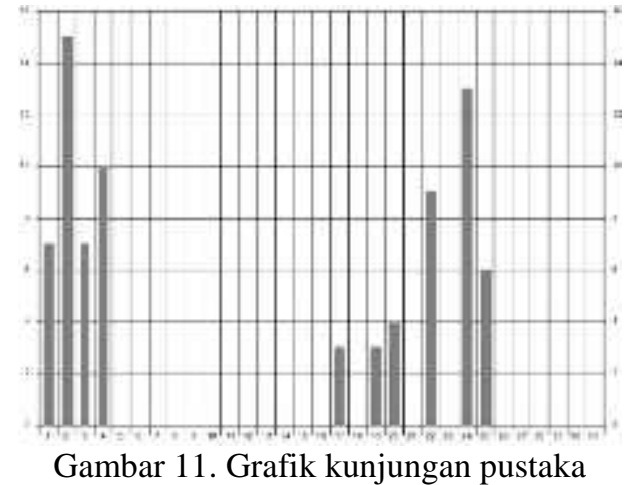

\section{Saran}

Sistem smart library tersebut tidak lepas dari kekurangan, oleh karenanya untuk melengkapi sistem aplikasi smart library agar tampak lebih baik maka perlu dikembangkan dengan menu tambahan lainnya yang lebih detail sesuai dengan kebutuhan yang akan datang.

\section{Daftar Pustaka}

[1] M.Aittola, T Ryhanen, dan T.Ojala, Smart Library-Location-Aware Mobile Library Services. University of Oulu: Finland, 2003.

[2] R.A. Barysev dan O.I.Babina (n.d.), Smart Library Concept in Siberian Federal University. Library and Publishing Complex of Siberian Federal University: Krasnoyarsk, 2013.

[3] P. Griffiths, Smart Libraries - Smart Librarians!. LAI/CILIP Ireland Joint Conference, CILIP: Ireland, 2010.

4] C. Jones, \& B. Shao, The Net Generation and Digital Natives: implication for Higher Education. A Literature Review, Higher Education Academy: York, 2013.

[5] R. Kasali, Let's Change: Kepemimpinan, keberanian, dan perubahan. Penerbit Buku Kompas: Jakarta, 2014.

[6] Mind Tools Ltd.. SMART Goals: How to make your goals achieveable, 2016.

[7] M. Prensky, Digital Natives, Digital Immigrants. On the Horizon. MCB University Press, Vol. 9, No. 5, October, 2001.

[8] A. Surachman, Analisis Pengaruh Perceived Usefulness, Perceived Ease of Use, Subjective 
Norm, Mobility, dan Use Situation terhadap

Niat Individu dalam menggunakan M-

Library, Universitas Gadjah Mada:

Yogyakarta, 2013.

[9] S. Wang, The Resource Sharing and

Cooperative Development of Smart ibraries in

Asia, JoLIS. Vol. 82. Pg. 1-12, 1 May 2013.

[10] Muchyidin, S dan Mihardja, Perpustakaan,

Bandung PT.Puri Pustaka, 2008.

[11] S. Agus. Membuat Aplikasi Absensi Dan Kuesioner untuk Panduan Skripsi. PT. Elex

Media Koputindo. Jakarta. 2012. 